\title{
INFLUENCE OF INSECT AND SEED SAMPLE SIZE AND HEAT TREATMENT ON THE INFESTATION OF CALLOSOBRUCHVS CHINENSIS (L.) ON MUNGBEAN, VIGNA RADIATA (L) Wilczek *)
}

\author{
ELISA M. BucruANON ${ }^{1}$ and BELEN MORALLO-REJESUS ${ }^{2}$ \\ ${ }^{1}$ Crops Research Division, Philippine Council for Agriculture, Forestry and Natural Resources Research \\ and Development, 4030 Los Banos, Laguna, Philippines \\ ${ }^{2}$ Department of Entomology, College of Agriculture, University of the Philippines at Los Banos, 4031 \\ College, Laguna, Philippines
}

\begin{abstract}
The influence of different insect and seed sample size and heat treatment on the infestation of bean weevil, Callosobruchus chinensis on mungbean, $\mathrm{Vjg} / \mathrm{m}$ radiata (L.) Wilczek, was studied.

Insect and seed sample size as well as varieties/genotype had significant influence in obtaining large responses in the number of eggs and progenies of the bean weevil.

Use of at least 10 adult weevils to infest test samples containing at least 40 seeds for a 5 -day oviposition period should produce reliable results when infesting mungbean seeds with unsexed weevils.

Dry heat treatment was very effective in disinfesting mungbean seeds from the bean weevil in different developmental stages. It improved germination depending upon the condition of the seed before treatment and certain temperature limits.

A suggested treatment for mungbean dismfestation using dry heat would be $60^{\circ} \mathrm{C}$ and $70^{\circ} \mathrm{C}$ for two-and one-hour treatments, respectively at $12 \%$ moisture content. For seeds in bulk, $60^{\circ} \mathrm{C}$ is much preferred.
\end{abstract}

Key words: Callosobruchus chinensis/Insect and seed sample size/Mungbean infestation/Heat treatment

\section{INTRODUCTION}

Bruchids are world-wide pests of mungbean (Vigna radiata (L.) Wilczek) in storage. The bean weevil, $C$. chinensis is one of the three bruchid species that infests mungbean in the field and during storage. Of the two given periods of attack, it is during storage that infestation results in greatest loss.

Measures to control the pest include among others the use of bruchid resistant cultivars and selective insecticides. Much effort has been directed towards the screening or evaluation of chemical insecticides, vegetable oils and plant products effective hi controlling bruchids, as well as in the development of resistant varieties (Duguet and Wu 1986; Davis et al 1984; Varma and Pandey 1978; Pandey et al. 1981; Epino and Morallo-Rejesus 1982).

* Paper presented at the Symposium on Pest Management for Stored Food and Feed, 5-7 September 1995, Bogor, Indonesia. 
During the process of screening, however, certain ecological and biological factors may have their individual and interactive effects on the test insect. Current practice in routine screening studies particularly against bean weevils differs largely in the number of insects and seeds used and the length of time the weevils are allowed to oviposit on the seeds. The optimum number of insects and seeds to use and the minimum oviposition period that should produce reliable results when infesting mung-bean seeds with bean weevils need to be determined. This has been established for maize and rice weevils (Widstrom el al. 1972) but not for bean weevils in mungbean.

Inasmuch as seeds should be clean and free from insects before use in all screening and other related studies, disinfestation is of prime importance and it must therefore be very effective to ensure that the seeds used for screening are clean. It becomes even more important with the bean weevil which has a particular way of development that prevents easy detection. Heat treatment at $70^{\circ} \mathrm{C}$ for 1 hour has been reported to be very effective in disinfesting maize seeds in China (Dr. Gonzalo de Leon, personal communication, 1988, CIMMYT Entomologist). Nevertheless, it needs to be further tested for its possible effect on the general condition of seed especially with legumes. This study therefore, was undertaken to determine the influence of insect and seed sample size and heat treatment on the infestation of bean weevil hi stored mungbean.

\section{MATERIALS AND METHODS}

\section{Influence of Insect and Seed Sample Sizes on Infestation of Bean Weevil on Stored Mungbean}

Two mungbean genotypes, V2802 and VC 1973A, which had shown resistance and susceptibility to bean weevil attack, respectively were used in the experiment (Talekar 1988; AVRDC 1986).

Four sample sizes of mungbean seeds $(10,20,40$ and 60 seeds per sample) were tested. Likewise, four weevil sample sizes (10, 20, 30 and 40 per sample) were tested.

Weevils were introduced into cups containing seeds of different sample sizes and held at $25^{\circ} \mathrm{C}$, $75 \%$ RH. A designated male/female ratio of adult weevils was not used hi this experiment because earlier studies reported a sex ratio (males:females) of 1.06:1.00 (Bato and Sanchez 1972) and 6:5 (Raina 1970) and therefore, it was assumed that there was a high probability of equal number of males and females in the weevil samples. Moreover, emergence of adult weevils took place at night and mating occurred within an hour after emergence from the seed. One mating is enough to ensure egg fertilization and laying starts a day after emergence. The weevils were allowed to oviposit for three periods: 3, 5 and 10 days. After each oviposition period, 
the weevils were removed and the eggs were counted. The cups were checked daily for progeny emergence.

The two mungbean genotypes, four bean weevil sample sizes, tiiree oviposition periods, and four mungbean seed sample sizes were combined in a factorial arrangement requiring $\%$ treatment combinations per replication. Three replications provided three blocks for analysis under a completely randomized design.

Seed damage and number of eggs and progeny per adult weevil in all treatments were determined.

Results from the analysis of variance were used to determine which combination(s) of the main effects influenced the measurement of bean weevil biology and mungbean quality. Comparisons between the responses within each factor were performed using the Least Significant Difference (LSD).

\section{Effect of Dry Heat Treatments on Different Stages of Bean Weevil}

Mungbean varieties, V2709 and MG-9, a resistant and a susceptible line, respectively were used. Each sample consisted of 2000 seeds which were exposed to 1000 adult bean weevils for oviposition.

For the egg stage disinfestation experiment, mungbean seeds were exposed to oviposition by the weevil for five days. After oviposition, seeds were mixed thoroughly and divided equally, and packed in small cotton bags before heat treatment. For the larval stage disinfestation test, the eggs laid on the seeds were allowed to hatch. The seeds were then mixed thoroughly, and divided equally into a sample size consisting of 100 seeds before dry heat treatment. For the adult stage disinfestation study, twenty-five bean weevil adults were placed in small bottles containing 100 seeds per replication. The bottles were then placed in the oven for heat treatment.

Heat treatments for disinfestation of all the developmental stages of the bean weevil were at $70^{\circ} \mathrm{C}$ and $80^{\circ} \mathrm{C}$ for one hour, and $60^{\circ} \mathrm{C}$ and $50^{\circ} \mathrm{C}$ for two hours. The treatments including the untreated control were replicated 4 times.

Mungbean seeds had $12 \%$ moisture content before heating.

Each of the samples was transferred into small bottles with a screen cover and arranged hi a completely randomized manner under room conditions at $25^{\circ} \mathrm{C}$ and $75 \% \mathrm{RH}$.

\section{Effect of Dry Heat Treatments on Mungbean Seed Vigor}

Germination tests according to the AOSA (1981) "Rules for Testing Seeds" was conducted to evaluate the damage on the seeds because of the exposure to heat. Seedling Growth Rate (SGR) vigor test was carried out. 


\section{RESULTS AND DISCUSSION}

\section{Influence of Insect and Seed Sample Sizes on the Infestation of Bean Weevil on Stored Mungbean}

Main effects and first-order interactions that significantly influence the number of eggs laid by the bean weevil, progeny produced per adult parent weevil, and percent damaged seeds are shown in Table 1. Of the four principal factors tested in this study, mungbean variety or genotype (v), bean weevil sample size (b), and seed sample size (s) were the most significant factors influencing weevil infestation.

Table 1. Summary of $F$ values for die main effects and interaction in the analysis of variance of factors mat influenced the number of bean weevil eggs and progeny per adult and percent damaged seeds ${ }^{1}$.

\begin{tabular}{|c|c|c|c|c|}
\hline Source of variation & $\overline{\mathrm{DF}}$ & $\begin{array}{l}\text { No. of eggs } \\
\text { peradulr }\end{array}$ & $\begin{array}{l}\text { No. of progeny } \\
\text { peradulr }^{2}\end{array}$ & $\begin{array}{l}\text { Percent damaged } \\
\text { seeds }^{3}\end{array}$ \\
\hline Variety $(\mathrm{v})$ & 1 & $462.05^{* *}$ & $2720.19^{* *}$ & $4217.7^{* * *}$ \\
\hline Bean weevil samples (b) & 3 & $36.94 * *$ & $225.18 * *$ & $4.1 * *$ \\
\hline Seed samples (s) & 3 & $41.04 * *$ & $181.54 * *$ & $2.69 *$ \\
\hline Oviposition period (o) & 2 & $2.63 \mathrm{~ns}$ & $<1 \mathrm{~ns}$ & $<1 \mathrm{~ns}$ \\
\hline $\mathrm{vxb}$ & 3 & $15.3^{* *}$ & $83.87 * *$ & $4.1^{* *}$ \\
\hline $\mathrm{VXS}$ & 3 & $2.43 \mathrm{~ns}$ & $61.64 * *$ & $2.69 *$ \\
\hline $\mathrm{V} \times \mathrm{O}$ & 2 & $<1 \mathrm{~ns}$ & $<1 \mathrm{~ns}$ & $<1 \mathrm{~ns}$ \\
\hline bxs & 9 & $<1 \mathrm{~ns}$ & $3.57 * *$ & $1.87 \mathrm{~ns}$ \\
\hline $\mathrm{b} \times \mathrm{o}$ & 6 & $<1 \mathrm{~ns}$ & $<1 \mathrm{~ns}$ & $1.23 \mathrm{~ns}$ \\
\hline s x o & 6 & $2.61^{*}$ & $1.05 \mathrm{~ns}$ & $1.87 \mathrm{~ns}$ \\
\hline $\mathrm{vxb} \mathrm{xs}$ & 9 & $<1 \mathrm{~ns}$ & $1.53 \mathrm{~ns}$ & $<1 \mathrm{~ns}$ \\
\hline $\mathrm{v} \times \mathrm{b} \times \mathrm{O}$ & 6 & $<1 \mathrm{~ns}$ & $<1 \mathrm{~ns}$ & $1.23 \mathrm{~ns}$ \\
\hline Vxs xo & 6 & $<1 \mathrm{~ns}$ & $<1 \mathrm{~ns}$ & $<1 \mathrm{~ns}$ \\
\hline bxs xo & 18 & $<1 \mathrm{~ns}$ & $<1 \mathrm{~ns}$ & $<1 \mathrm{~ns}$ \\
\hline vxbxsxo & 18 & $<1 \mathrm{~ns}$ & $<1 \mathrm{~ns}$ & $<1 \mathrm{~ns}$ \\
\hline Error & 192 & & & \\
\hline
\end{tabular}

\footnotetext{
$*=$ significant at $5 \%$ level

$* *$ significant at $1 \%$ level

$\mathrm{ns}=$ not significant

$1=$ average of the three replicates

2 = based on data analyzed using the $\log (\mathrm{x}+1)$ transformation

$3=$ based on data analyzed using the Arc sine transformation
}

Four significant interactions involved seed sample size. The number of eggs per adult parent weevil was significantly influenced by the interaction of seed sample size and duration of oviposition (Fig. 1). Eggs per adult markedly increased with larger 
seed sample size. This is probably due to the greater number of seeds available for oviposition with more seeds thus lessening competition among the weevils.

Comparison among the three oviposition periods (3,5 and 10 days) revealed that there was no significant differences between 3-day and 10-day oviposition period.

The highest number of eggs laid by the weevils occurred at the 40-seed and 60-seed samples and at the 5-day oviposition period. Although the highest egg count was obtained at the 60-seed sample this was comparable with that of the 40-seed sample at 5-day oviposition period and the latter was preferred. It was the minimum seed sample size and shortest duration of oviposition that yielded a high number of eggs per adult parent weevil.

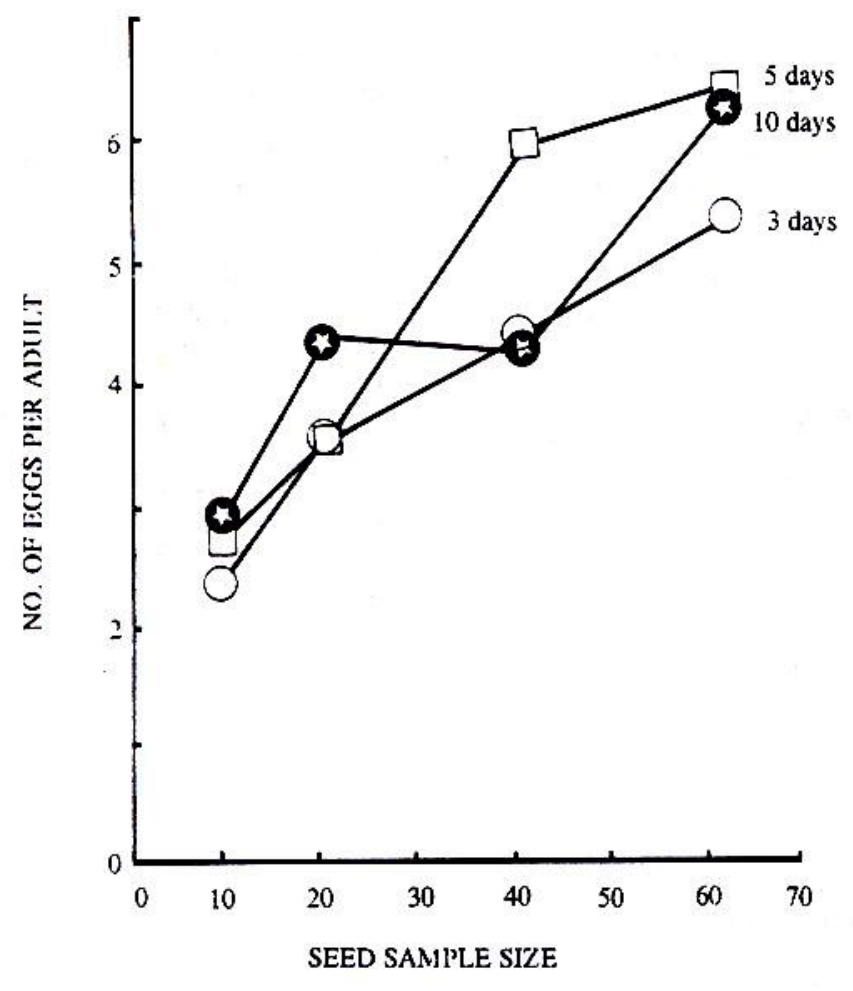

Fig. 1. Number of bean weevil eggs laid per adult with increasing mungbean seed sample size for three oviposition periods

The interaction of the varying level of mungbean seed and parent bean weevils strongly influenced the number of progeny obtained per adult (Fig. 2). The highest number of progeny (14/parent weevil) was obtained from 10 weevils/60 seeds. Nevertheless, at 10 weevils/40 seeds, the same trend was observed, i.e. number of 
progenies was still high (8/parent weevil). The highest number of progenies per adult weevil obtained at 10-weevil sample size was suspected to be due to competition between larvae that existed at higher weevil sample size (20,30 and 40). This resulted in only a few surviving adults.

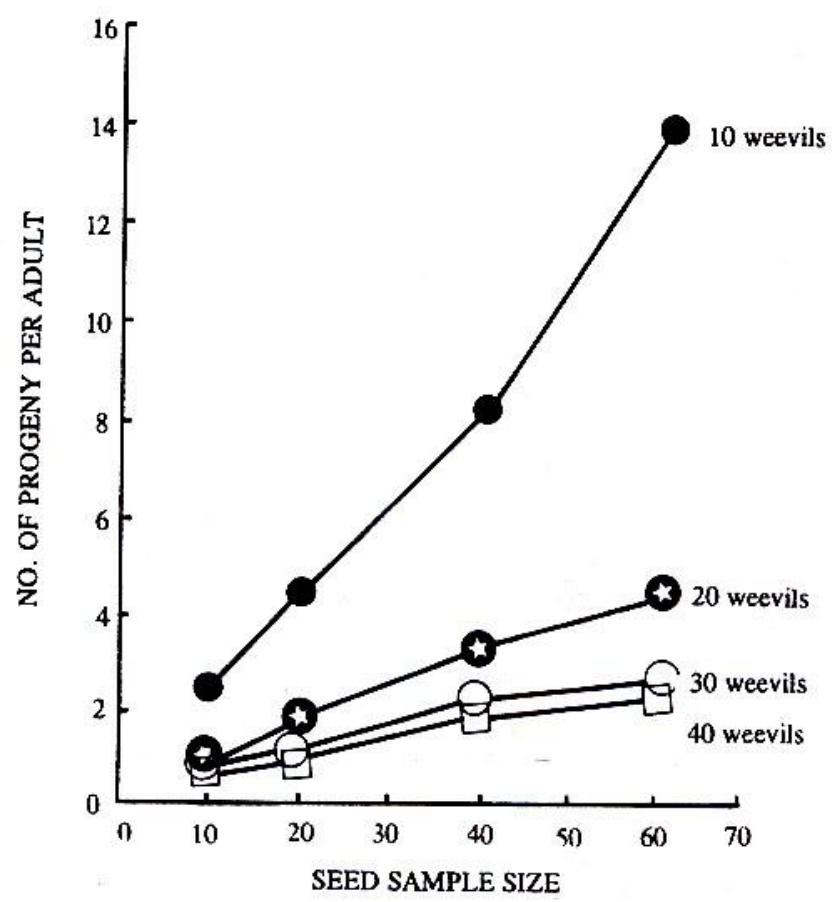

Fig. 2. Number of bean weevil progenies per adult with increasing seed sample size for four bean weevil sample sizes

A highly significant effect was obtained in the number of progenies per adult as a result of the interaction between seed sample size and genotype (Fig. 3). Many bean weevil progenies emerged from the susceptible seeds. However, it was quite interesting to note that both genotypes received, more or less the same number of eggs as shown by their nonsignificant F-value (Table 1). The marked difference in the number of progenies suggests failure of eggs to hatch or failure of larvae to develop into adult weevils in the resistant mungbean genotype.

The effect of seed genotypes and seed sample size was also significant in terms of percent damaged seeds (Fig. 4). Complete damage in susceptible seeds indicated that all seeds had eggs deposited on them. In the resistant genotype, however, percent 


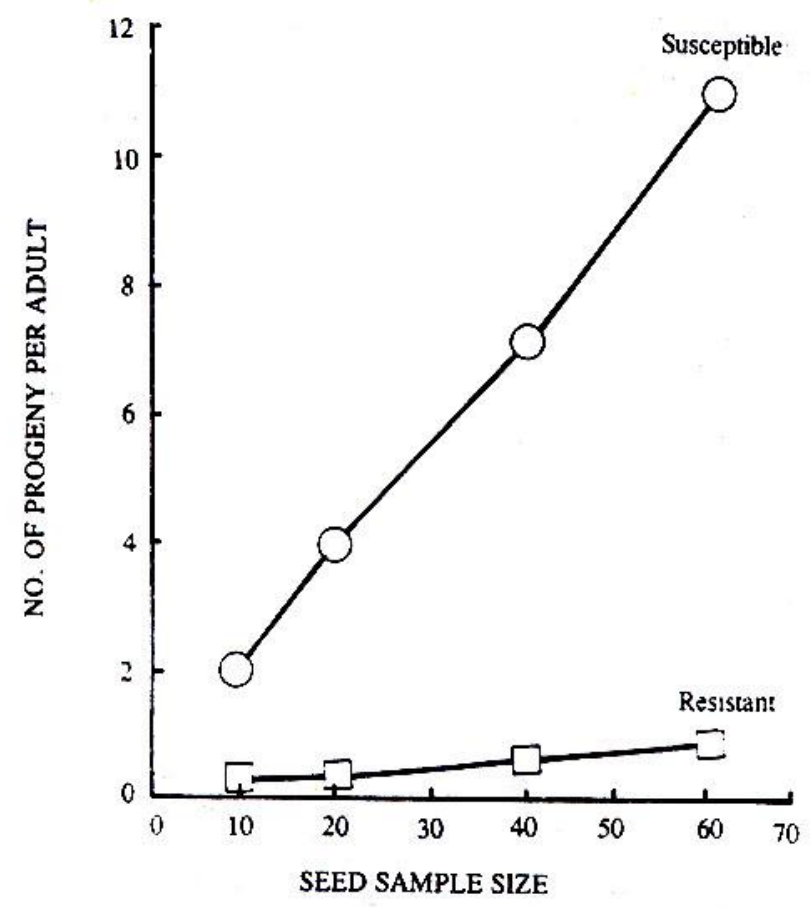

Fig. 3. Number of bean weevil progenies per adult with increasing seed sample size for two mungbean varieties

damaged seeds significantly decreased at higher seed sample size. This shows that some seeds of the resistant genotype were missed by the females or eggs were laid but failed to develop into adult weevils. The proportion of these seeds without eggs increased as the number of seeds increased. The absence of eggs or progeny on some seeds of the resistant genotype, however, indicates that they are unsuitable for oviposition or larval growth and development. The reason why some seeds of the resistant genotype are unsuitable for oviposition is not yet clear.

Four highly significant interactions involved bean weevil sample size (Table 1). The seed genotype $x$ bean weevil sample size interaction (Fig. 5) strongly influenced the number of eggs per adult. As the number of adult parent weevils increased, the number of eggs laid decreased in both susceptible and resistant genotypes. Interference among weevils or eggs laid early by the weevils could make the bean testa less attractive (rougher) for oviposition. Probably, it could be due to the effect of crowding of weevils or competition for oviposition sites. Ten weevils/40 or 60 seeds seem to be the ideal insect and seed sample sizes to use in the interaction/screening studies for 


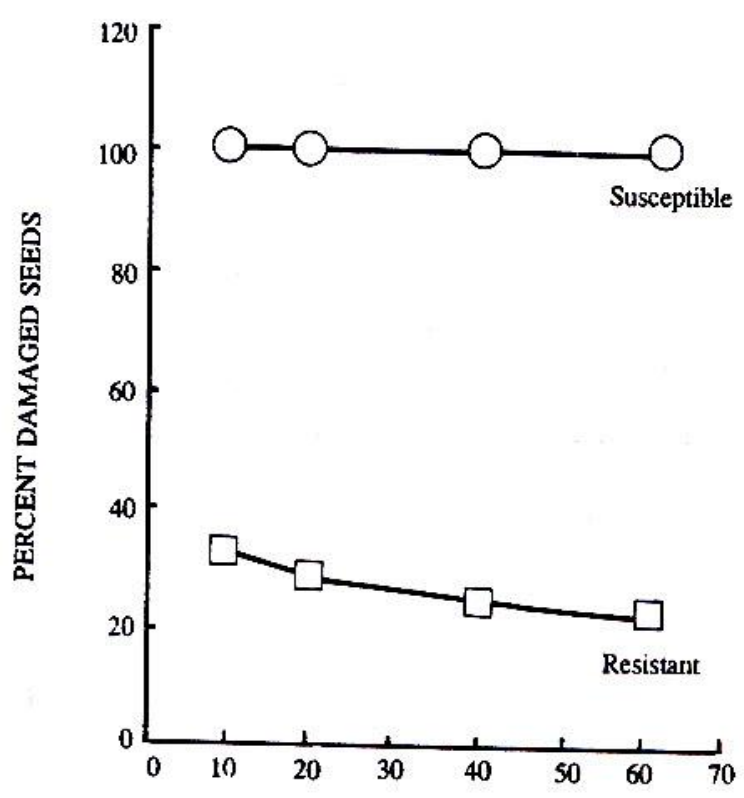

SEED SAMPLE SIZE

Fig. 4. Mean percent of damaged seeds as influenced by increasing seed sample size for two mungbean varieties

bean weevils in mungbean since the highest number of eggs and progenies per adult occurred in this level. The degree of egg aggregation at the 10,20 and 30-weevil samples on the resistant genotype was less than the susceptible counterpart but rose significantly between 30 - and 40 -weevil samples. The reason for this significant increase is not yet clear.

The number of progeny per adult weevil was strongly affected by bean weevil sample size and genotype interaction (Table 1). The number of adult progeny emerging decreased as bean weevil number increased in both susceptible and resistant genotypes (Fig. 5B). The result is consequent with the trend of result on the number of eggs (Fig. 5A). Adult weevil production depends on the hatchability of eggs which in turn is influenced by collisions between adults and laid eggs (Nwanze el al. 1975). Egg hatchability and larval growth and development may have been affected also by some resistance factors present in the seed. The susceptible and resistant genotypes varied in their reaction to bean weevil numbers as indicated in the percentage of damaged seeds (Fig. 5C). The seeds of the susceptible genotype were completely 
Influence of Insect and Seed Sample Size and Heat Treatment - E. M. Buctuanon and B. Morallo-Rejesus
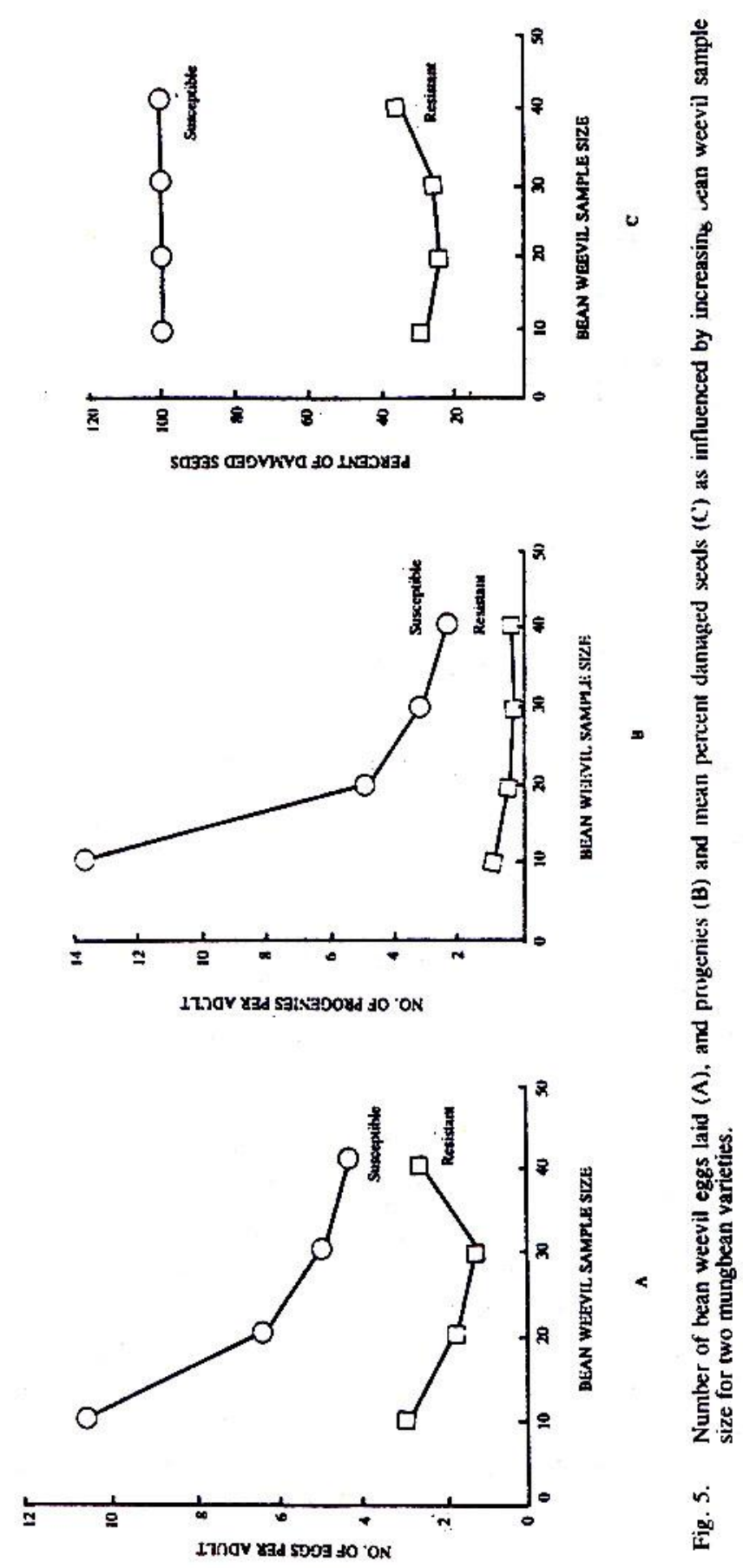

 
damaged. In the resistant genotype, the percent damaged seeds in the 10-, 20- and 30-weevil samples were invariably less than the 40 -weevil samples. It was noted, though, that there were significantly more eggs laid at 40-weevil sample in the resistant genotype (Fig 5A), yet the resulting number of progenies did not give the same trend of result (Fig. 5B). Not many weevil progenies were produced at 40 -weevil sample. This result is consistent with the previous discussion that progeny production on resistant seeds was suppressed due to some resistance factors present in the seeds.

\section{Effect of Dry Heat Treatments on the Different Stages of Bean Weevil}

In the egg stage disinfestation experiment, results show that heat treatment significantly influenced the number of adult bean weevils that emerged from the disinfested mungbean seeds. No adult weevils emerged from seeds treated at $60^{\circ} \mathrm{C}, 70^{\circ} \mathrm{C}$ and $80^{\circ} \mathrm{C}$, and exposed for 2-hour and 1-hour, respectively (Fig. 6A). Weevils survived from dry heat treatment at $50^{\circ} \mathrm{C}$ for two hours. Likewise, temperatures at $70^{\circ} \mathrm{C}$ and $80^{\circ} \mathrm{C}$ applied for one hour and $60^{\circ} \mathrm{C}$ for wo hours killed all the larvae (Fig. $6 \mathrm{~B})$. Higher number of larvae survived from $50^{\circ} \mathrm{C}$ for 2 -hour exposure which was comparable to the control. Moreover, no adult weevils survived after exposure to $70^{\circ} \mathrm{C}$ and $80^{\circ} \mathrm{C}$ for one hour and at $60^{\circ} \mathrm{C}$ for 2 hours (Fig. 6C). Only $64 \%$ and $79 \%$ of adult weevils were killed at $50^{\circ} \mathrm{C}$ for 2 -hour exposure in susceptible and resistant lines, respectively.

These results indicated that effective control was achieved using dry heat treatments at $60^{\circ} \mathrm{C}$, $70^{\circ} \mathrm{C}$ and $80^{\circ} \mathrm{C}$ for two- and one- hour exposure, respectively. Insect eggs, larvae and adults were completely killed at these temperature levels and duration of exposure, thus indicating that this temperature range could be used in disinfesting mungbean seeds depending upon its effect on the viability and vigor of seeds which is discussed in the succeeding topic.

\section{Effect of Dry Heat Treatments on Mungbean Seed Vigor}

The effect of dry heat temperatures on the vigor of seeds of two mungbean genotypes based on the percentage of normal seedlings, plumule length and dry matter weight is shown in Table 2. Results showed that dry heat treatments increased the percentage of normal seedlings in both susceptible and resistant genotypes (Fig. 7A). Highest and lowest percentages of normal seedlings from the resistant genotype were obtained at $70^{\circ} \mathrm{C}$ and $80^{\circ} \mathrm{C}$, respectively for one hour exposure. Lower temperatures $\left(50^{\circ} \mathrm{C}\right.$ and $60^{\circ} \mathrm{C}$ ) but of longer duration of exposure (two hours) gave results comparable to that of the control and those exposed at $70^{\circ} \mathrm{C}$. The most pronounced increase in the percentage of normal seedling $(50.5 \%)$ with the susceptible genotype was 


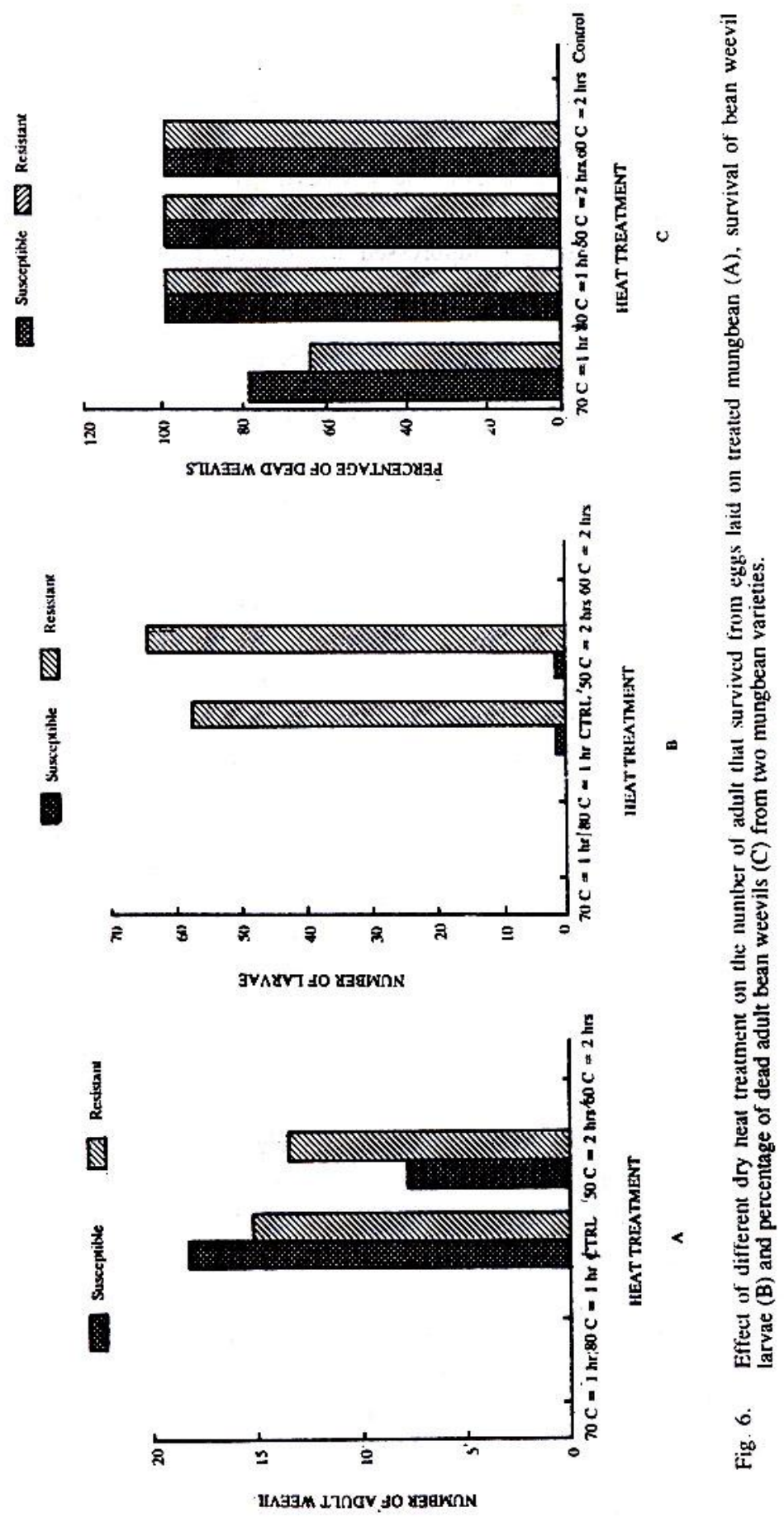


BIOTROPIA No. 10, 1997

Table 2. Summary of $F$ values of the analysis of variance on the effect of the different treatment levels and varieties on the percentage of normal seedlings, mean plumule length and weight ${ }^{1}$

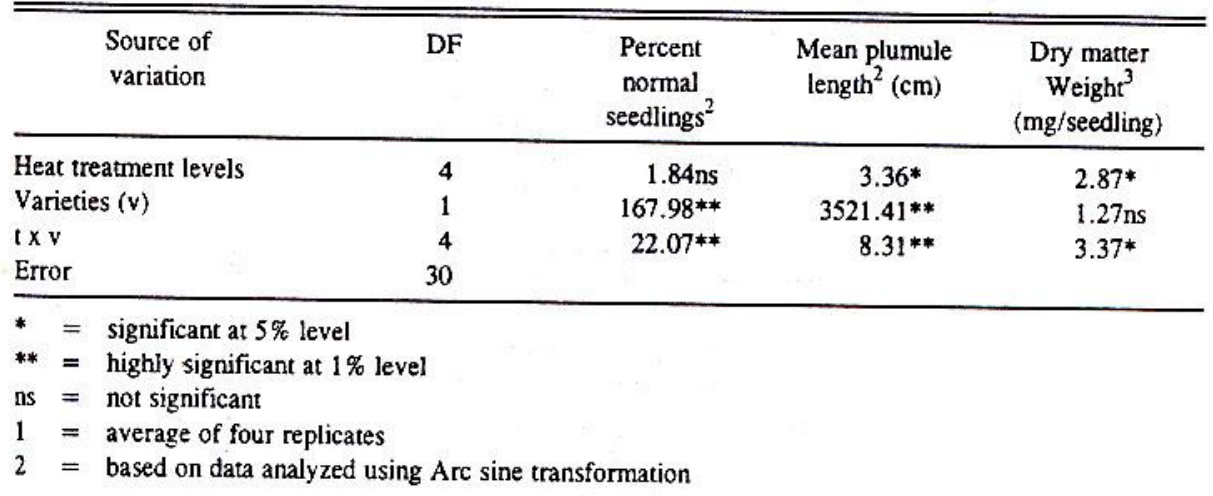

obtained from seeds exposed to $80^{\circ} \mathrm{C}$. No germination occurred from among those seeds in the control. There were hard seeds recovered from the susceptible genotype indicating the seeds to be probably dormant were broken by heat treatment specifically at higher temperature. Results clearly indicated that dry heat treatment tremendously improved germination of seeds. This may probably be due to the increased water permeability at the strophiole of the mungbean seeds. Mott and McKeon (1979) observed this phenomenon with dry heat treatments of stylo seeds, S. humilis.

The effect of different dry heat temperatures and genotype interactions on plumule length was highly significant (Table 2). Differences in plumule length were markedly evident between genotypes (Fig. 7B). In the resistant genotype, the plumule length tended to be longer, comparable with the control treatment, from seeds exposed to higher temperatures $\left(70^{\circ} \mathrm{C}\right.$ and $\left.80^{\circ} \mathrm{C}\right)$ for one hour. Seeds from the control treatment failed to germinate.

There was no significant difference in the dry matter weight obtained between genotypes, and in all levels of dry heat temperatures in the resistant genotypes (Fig. 7C). Highest dry matter weight was obtained in $60^{\circ} \mathrm{C}$ treatment for two hours in the susceptible genotype as compared to the $80^{\circ} \mathrm{C}-1$ hr treatment.

Heating mungbean seeds with dry air generally improved germination. However, certain important factors and/or seed conditions should be considered before treatment. In this particular study, resistant variety seemed to respond well to heat treatments especially at higher temperatures, but only to a maximum of $70^{\circ} \mathrm{C}$. Dry heat temperatures of $80^{\circ} \mathrm{C}$ significantly damaged the seeds as indicated by the lowest percentage of germination and normal seedlings obtained from this treatment level. Variety can be a factor in heat damage resulting perhaps from differences in hardness, protein content or the variety as such (Ghaly and Taylor 1982). 
Influence of Insect and Seed Sample Size and Heat Treatment - E. M. Buctuanon and B. Morallo-Rejesus
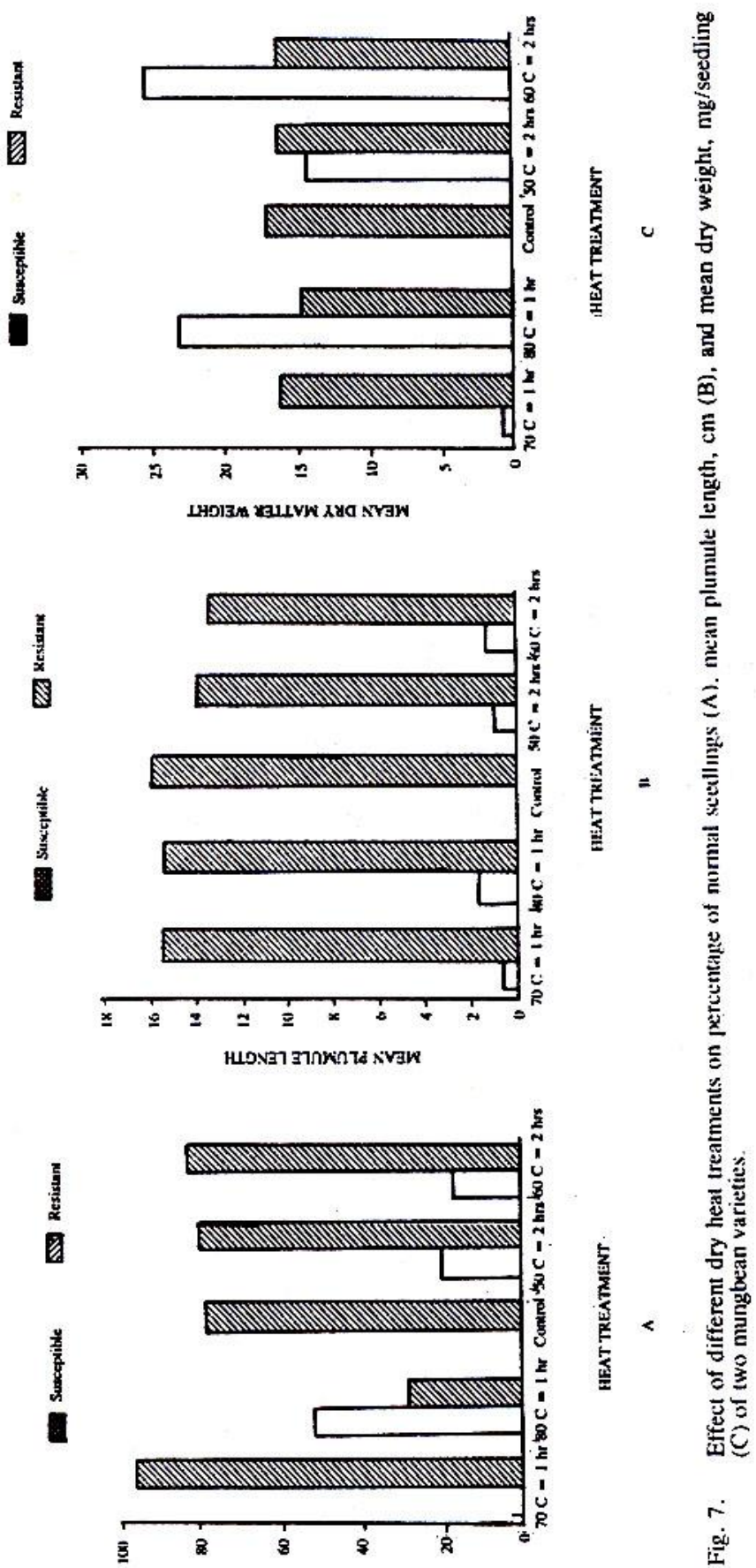
Mungbean seed vigor as evaluated, based on the four parameters, seemingly is not affected detrimentally by dry heat treatments up to certain limits. Dry heat treatment of seed at $60^{\circ} \mathrm{C}$ is safer to use. The $60^{\circ} \mathrm{C}$ temperature level was found to be equally effective when compared with $70^{\circ} \mathrm{C}$ and $80^{\circ} \mathrm{C}$ in disinfesting mungbean seeds from the bean weevil, C. chinensis.

\section{SUMMARY AND CONCLUSION}

The influence of insect and different seed sample sizes and heat treatment on the infestation of bean weevil, Callosobruchus chinensis (L.) on mungbean was determined. Insect and seed sample sizes as well as variety/genotype had significant influence in obtaining high production of eggs and progenies of the bean weevils. These different parameters are tp be considered in screening studies.

Bean weevil eggs laid per adult increased with high seed numbers and the number of progenies decreased with increasing numbers of parent weevil. The weevils per 60 or 40 seeds in 5-day oviposition periods provided the greatest frequency of significant responses in the number of eggs and progeny per adult weevil and percentage of damaged seeds. These are the minimum number of weevils necessary in a parent population and the practical seed sample size that would support the minimum number of days of oviposition to obtain maximum oviposition and/or infestation for screening studies.

The number of weevil progenies differed in the resistant and susceptible genotypes, but no variation was observed in the number of eggs laid. The number of eggs laid and emerging progenies decreased as the number of parent weevils introduced was increased in both susceptible and resistant genotypes. Seeds of susceptible genotypes were completely damaged in all seed density levels. However, percent damaged seeds decreased at higher seed densities in resistant genotypes.

Dry heat treatment was found to be very effective in disinfesting mungbean seeds from the different development stages of bean weevil. Dry heat treatment improved germination and is not detrimental to the seeds regardless of genotype, depending however, on the condition of the seed before treatment which affects the dry heat temperature requirement and/or limits of the seeds. Dry heat treatment of seeds at $60^{\circ} \mathrm{C}$ for 2 hours and $70^{\circ} \mathrm{C}$ for 1 hour exposure at $12 \%$ moisture content give complete insect control and is safer to use. Heat treatment at $60^{\circ} \mathrm{C}$ however, is much preferred in disinfesting big bulk of seeds. 


\section{LITERATURE CITED}

AOSA. 1981. Rules for testing seeds. 6(2): 30, 113 .

AVRDC, 1986. AVRDC Progress Report. 1984. Asian Vegetable Research and Development Center (AVRDC), Shanhua. Taiwan, $480 \mathrm{p}$.

BATO, S.M. and F.F. SANCHEZ. 1972. The biology and chemical control of Callosobruchus chinensis (Linn.) (Coleoptera: Bruchidae). Philipp. Ent. 2(3): 167-182.

DAVIS, R., J. BOCZEK, D. PANKIEWICZ-NOWICKA and M. KRUK. 1984. Efficacy of tricalcium phosphate as a legume grain protectant. Proc. Third Int. Working Conf. on Stored-Product Entomology. Kansas State University, Manhattan, Kansas, p. 256-261.

DUGUET, J.S. and G.X. Wu. 1986. Assessment of activity of deltamethrin against Callosobruchus chinensis L. and Callosobruchus maculatus Fab. (Bruchidae). Int. Pest Control. 28: 36-41.

EPINO. P.B. and B. MORALLO-REJESUS. 1982. Mechanisms resistance of mungbean (Vigna radiata (L.) Wilczek) to Callosobruchus chinensis (L.). Philipp. Ent. 5: 447-462.

GHALY.T.F. and P. A. TAYLOR. 1982. Quality effects of heat treatment of two wheat varieties. Jour. Agric, and Eng'g. Res. (27): 227-234.

мотт. J.J. and G.M. McKEON. 1979. Effect of heat treatments in breaking hardseededness in four species of Stylosanthes. Seed Sci. \& Tech. 7: 15-25.

NWANZE. F.F., E. HORBER and C.W. Pms. 1975. Evidence for oviposition preference of C. maculatus for cowpea varieties. Environ. Ent. 4: 409-412.

PANDEY. G.P.. R.B. DOHAREY and B.K. VARMA. 1981. Efficacy of some edible oils for protecting greengram against the attack of Callosobruchus maculatus i.Fabrj. Indian Jour. Agric. Sci. 51: 910-912.

RAINA, A.K. 1970. Callosobruchus spp. infesting stored pulses (grain legumes) in India and a comparative study of the biology. Indian Jour. Entomol. 32: 303-310.

TALEKAR. N.S. 1988. Biology, damage and control by bruchid pests of mungbean. Proc. of the Second Int. Symp. on Mungbean. p. 329-342.

VARMA, B.K. and G.P. PANDEY. 1978. Treatment of stored greengram seed with edible oils for protection from Callosobruchus maculatus (Fab.). Indian Jour. Agric. Sci. 48: 72-75.

WIDSTROM. N.W., L.M. REDLINGER. and W.J. WISER. 1972. Appraisal of methods for measuring com kernel resistance to Sitophilus zeamais. Jour. Econ. Ent. 65: 790-2. 